\title{
Need Analysis of Text for Translation Material in Universitas Negeri Padang
}

\author{
Try Ulva Yeni ${ }^{1, *}$ Havid Ardi $^{2}$ \\ ${ }^{1}$ English Education Graduate Program, Universitas Negeri Padang, Padang, Indonesia \\ ${ }^{*}$ Corresponding author. Email: Ulvaananta024@gmail.com
}

\begin{abstract}
Globalization, industrialization, technology and social media have affected the progress of translation studies from different sides. The present situation makes the need for translation is increasing day by day and the materials to be translated are growing more and more numerous. This research explores the needs of translations' materials related text types in bachelor degree at Universitas Negeri Padang that focused to the compatibility of the translation materials to the translation market. The questionnaires were used because the instrument and therefore the data were analyzed by using Likert Scale. Then, instructors, professionals who are involved within the translation agency were interviewed. To do so, the researcher designs this study as a descriptive research. Therefore, the results show that there are 15 lacks of text types in translation course at Universitas Negeri Padang. additionally, the purpose of departure during this study was that translations' materials related text types and therefore the translation market as two parties to translation service provision should be in close interaction so as to enhance the standard of translation class in higher-education institutions and therefore the quality of translation done on the market. The findings of this research are expected to provide valuable information for curriculum designers in developing learning materials focus on translation subject with the materials are related to the students' need in the translation market.
\end{abstract}

\section{Keywords: Translation course, translations' needs, materials' lacks, text types, market demands}

\section{INTRODUCTION}

Translation is during all one amongst one in every of one among the areas of competence reserved for college students of English education in a wide selection of universities within the world. Translation helps students to be ready to transfer a message from foreign language (source language) into local language (target language) or vice versa. Therefore, the Department of English education throughout the university in Indonesia provides Translation subject from English to Indonesian and the other way around. Besides, it are often noted that teaching translation course is a neighbourhood where theory and practice are connected, which ideally means translation teachers apply theoretical ideas in their own pedagogic practice, in other words having a good knowledge on various world matters and understanding translation users' needs.

Every translation activity has one or more specific purposes. Priyanto Ardi [1] mentions, one primarily goal of translation is to serve cross-cultural bilingual communication among people. This suggests that translation isn't merely an activity of rewording or changing the language to the target language, but it's an activity that transfer messages, ideas, perspectives or knowledge to readers from different background of cultures. Furthermore, within the past few decades, this activity has developed due to the rising international trade, and therefore the expansion of the mass media and technology. For this reason, the translator plays a crucial role as a bilingual or multi-lingual cross-cultural transmitter of culture and truths by attempting to interpret concepts and speech during a sort of texts as accurately as possible. For example, many social media needs that require translator services in the present, this is certainly very beneficial for English students. The researcher conducts informal interviews with several English students especially those who have already taken a translation classes, they said that they often got some offers to translate journals, advertisements, songs, books, movie subtitles and also subtitles of certain forms such as $v \log$ on Youtube.

In general, translation subject as formal professional activity is sort of new within the academic field especially at university level. In some countries translation has become an independent major and a few as new terms that are coined for the new subject called Translation. Additionally, in Canada it's taught under the topic of "Translatology," in Spain it's referred to as "Traductologia," and it's called as "Translation Studies" in Belgium and Netherlands [2]. In Indonesia, translation subject may be a part of learning in university. Others, while teaching and learning translation course, the teachers should plan to make sure that the course remains aligned with the learners' needs. In quest of this issue, the role of 
needs analysis in translation course shouldn't be underestimated. For this reason, an effort is formed to adopt a framework for translation course design which employs needs analysis as its start line getting to highlight the views of all stakeholders within the process in fact and syllabus design, materials and evaluation of the effectiveness, efficiency and the needs of students in the implementation of the translation course. Being aware of the requirements of the learners influences not only the content of the course but also what potential are often exploited through such course. Needs analysis may be a complex process which has got to take under consideration what Hutchinson and Waters [3] define as "target needs", what learners need to know in the target situation, for instance "learning needs", what learners got to find out the needs in teaching and learning process.

In addition, in a more modern view, we should not only take into account "target needs" and "learning needs", objective needs, but also learners' subjective needs, that is, their affective needs, such as their interests, wishes, expectations and preferences [4]. It is generally acknowledged that syllabus development should involve the learners. On the other hand, needs analysis is an easily accessible tool for syllabus development, enabling teachers to continuously explore learners' individual characteristics and address their specific needs. In order to achieve the broad goals of the course, the teaching material should cover theoretical as well as practical aspects such as translating various text types. Therefore, text exercises that are related with the needs of the translation market at this time are aspects that must be observed in a course. Teachers need to explore the gap between materials of translation and practice in the real field, so the aim of the class would be to prepare students for a career as translator.

Need analysis can be seen as an instrument to find the deficit of students for better material adaptation, adoptions or development in the teaching learning process. As Navid and Zahra [5] argue, need analysis is that the door opening to the entire program planning process, that's to mention, it's the very initiative to be taken and plays an important role within the design and development of any program. it's necessary to spot needs to become conscious of the training conditions of people or group to align these with their physical, intellectual and emotional possibilities also on devise learning materials which can answer what's to be taught and thus to clarify the pedagogical objectives pursuant to negotiating with the learners [6].

Furthermore, in recent years, need analysis of translation needs which identifying the lacks of materials in translation course mostly discussed by many researchers. There were several study related to the need of students in studying translation. Many researcher conducted research about translation materials. They are conducted by Endah, Manipuspika [7]; Sezer, Zeda [8]. In addition many researchers also conducted research about need analysis for developing translation text book in order to meet the gap between materials offered and market demands. They are: [9], [10].
[11] Discusses about theory in translator training: some observations about syllabus design. Furthermore, in hers research, She suggested that every effort should be made to harmonious the formal theory component with everything else that goes on in the translation program, so that theory seen to be relevant to practice. In addition, Adrienn [12] exploring learners' needs and expectation: translating texts in an English bachelor program, at a Hungarian Collage. In the meanwhile, Coban [13] analyzes the required abilities and materials text in translation course.

However, there were still limited researchers conducted about students' needs of translation course and translation market or career. Thus, this research necessary to be conducted since this research can be used to be an orientation to analyze the students' need in translation materials that related to the translation market. This research reveals that the need for translators is very important because there are many translation jobs in the field that require translators to be able to translate various types of texts, such as legal, political, news, insurance texts as well as various other types on social media.

\section{METHODOLOGY}

This study was conducted with the aim of exploring, analyzing and explaining the lacks of text types of Translation Studies at bachelor level with regard to the market needs using the perception of students, course instructors, graduates and professionals. This research is classified into descriptive research. According to Gay [14] descriptive research involves collecting data in order to answer questions concerning the current status of the subject of the study. Moreover, Seliger and Shohamy in Gay [15] state that descriptive research is used to obtain the information concerning with the phenomena that occur when the research is done.

The subjects of this research are English students who have taken translation course at Universitas Negeri Padang. As for the themes within the category of Graduates, variety student who majored in Master's degree of Translation Studies at Universitas Negeri Padang involved within the current study considering that they're potentially precious data sources in identifying the needs and therefore the current conditions of present programs at university. Semi-tructured interviews were conducted with the graduates. As for the structured interviews with course instructors, three instructors, who are the sole convenient choices, were chosen, all of whom are the lectures who is ever taught translation course at Universitas Negeri Padang. Further, Two professionals who were involved in translation business were chosen, this include people that work as translator. In order to explore students' needs, the researcher developed questionnaire which consist of 32 items of text types. The questionnaires are in Bahasa Indonesia, employing Likert scales items that the informants will choose by giving checklist mark $(\sqrt{ })$. The important scale comprised of the following descriptors: Strongly disagree, disagree, agree, strongly agree. 
In analyzing the questionnaire data, Likert Scale was used in this research as it is suggested by Gay [15]. He states that a Likert Scale asks an individual to respond a series of statement by indicating whether she or she is Strongly Agree (SA), Agree (A), Disagree (D), and Strongly Disagree (SD). The responses obtained from the students' questionnaires were converted to percentage. It was done by using the formula:

$P=\frac{F}{N} \times 100 \%$.

Finally, the mean score was consulted into four categories, they are:

Table 1. Likert Scale Mean Score

\begin{tabular}{|c|c|c|}
\hline $\begin{array}{c}\text { Point } \\
\text { Value }\end{array}$ & Explanation & Average Score \\
\hline 4 & Strongly Agree & $3.01-4.00$ \\
\hline 3 & Agree & $2.01-3.00$ \\
\hline 2 & Disagree & $1.01-2.00$ \\
\hline 1 & Strongly Disagree & $0.0-1.00$ \\
\hline
\end{tabular}

\section{RESULTS AND DISCUSSIONS}

A. Result

Lack is the difference between the student's present competence and the desire competence. Moreover, Hutchison [3] identifies lacks is about to find out the gap between students' current proficiency ad the target proficiency, so that the teacher or facilitator can decide which of the necessities the earner's lacks.

The important of teaching text types in translation classes cannot be overlooked for the purpose of communicative translation teaching. The materials lacks related of text types of English Department students in translation course at Universitas Negeri Padang have been identified based on the result of analysis the questionnaires given and conducted an interview.

The purpose of questionnaire is to find out the materials lacks for translation courses. The items of the questionnaires cover various types of texts that are often translated by the translators in the real work life. Furthermore, the respondents chose the alternative answer, i.e. strongly agree (4), agree (3), disagree (2), strongly disagree (1), based on the given indicators. The following table indicates the results of need analysis of materials' needs in translation course at Universitas Negeri Padang.

\section{Materials needs}

Table 2. Text Vocatives

\begin{tabular}{|l|l|l|l|l|l|}
\hline \multirow{2}{*}{ No } & \multirow{2}{*}{ Text types } & SD & D & A & SA \\
\cline { 3 - 6 } & & & & & \\
\hline 1. & Advertisement & 1 & 2 & 32 & 2 \\
\hline 2. & Announcement & 1 & 2 & 31 & 3 \\
\hline 3. & Complaints & & & 32 & 5 \\
\hline 4. & Notice & 2 & 1 & 32 & 2 \\
\hline
\end{tabular}

Based on the description of the table above, There are 4 texts belong to vocative's text, they are; advertisement, announcement, complaints and notice. Based on the table above, it can be seen that the analysis of respondents' respond of 'advertisement' with 3 in average. From data analysis, there are 32 of respondents chose to agree and 2 of them answered strongly agree, while 2 respondents answered disagree, moreover only one of respondent answered strongly disagree.

Next, the results of text number 2 shows that the average score is 2.97 . The analysis of questionnaire implied that 31 respondents answered agree, 3 of them chose strongly agree, while 2 stated disagree and 1 pointed strongly disagree. Furthermore, text number 3, based on the description of questionnaire data, translating text 'complaint' needed by the translation students. There are 32 of respondents answered agree while some of them chose strongly agree (5). Meanwhile, text 'notification' is expected by students as an exercise in a translation classes. This is indicated by the results of the analysis, there are about 32 of respondents who chose to agree, and few of them chose strongly agree (2) while 1 answered disagree. In addition, based on the result of in-dept interview with 2 graduates, they said that advertisement, announcement, complaints and notice are important as an exercise in translating text. Most of them believe that, by practicing translating those kind of texts will help students as translator familiar with the model or type of the text. Furthermore, they also stated that nowadays when the development of society growing rapidly, there are so many kind of advertisements published on certain platform in social media, for example Facebook, Instagram and also Youtube.

Furthermore, based on an interview conducted with a lecturer who teaches translation in the English Department of Universitas Negeri Padang, one of the lecturers said that now the translation is indeed directed at one of the textbased translations. In short, it also can be said that all of those text on the table above are needed for students as translator.

Table 3. Text Expressive

\begin{tabular}{|l|l|l|l|l|l|}
\hline \multirow{2}{*}{ No } & \multirow{2}{*}{ Text types } & \multicolumn{4}{|c|}{ Response } \\
\cline { 3 - 6 } & & SD & D & A & SA \\
\hline 1. & Speech & & & 35 & 2 \\
\hline 2. & Preach & & & 35 & 2 \\
\hline 3. & $\begin{array}{l}\text { Stand-up } \\
\text { comedy }\end{array}$ & 3 & 17 & 15 & 2 \\
\hline 4. & Biography & & 2 & 17 & 18 \\
\hline 5. & Plays & 1 & & 31 & 5 \\
\hline 6. & Poetry & 2 & 4 & 26 & 5 \\
\hline 7. & Prose & 1 & 2 & 32 & 2 \\
\hline 8. & Drama & 1 & 4 & 28 & 4 \\
\hline 9. & CV & & & 30 & 7 \\
\hline
\end{tabular}

Best on the result of questionnaire distributed to the respondents about the text types that would be needed for students to learn, it is figured out that the number of respondents expecting to learn 'preach' and 'speech' get the biggest numbers, then followed by 'plays', 'prose', 'CV', 'drama', 'poetry', 'biography' and 'stand-up comedy'. 
This could be seen from the data presented in table 3 indicating that there are two texts which are equal of the percentage of respondents (35 agree and 2 strongly agree) are willing to learn 'speech', further (35 agree, 2 strongly agree) expected to learn 'preach' in translation classes. Then, 31 respondents are willing to study 'plays' by stated agree, while 4 strongly agree and 1 of them strongly disagree. Furthermore, 32 respondents expected the lecturer present 'prose' as one of exercise in translation classes, and there are few respondents (2) answered strongly agree, while 2 of them stated disagree and 1 to strongly disagree.

Furthermore, related to other types of expressive text the respondents shared that most of them 32 (28 agree, and 4 strongly agree) expected the lecturer use 'drama' as one text for translating practice in the course. Meanwhile, there are few of respondents who pointed disagree and strongly disagree (4 disagree, 1 strongly disagree) if 'drama' used in translating activity. There are 31 (26 agree and 5 strongly agree) of respondents who are expected 'poetry' used in translation classes. Besides, 4 respondents pointed disagree and 2 of them answered strongly disagree. In addition, student said that translating poetry is considered one of the most complicated types of translations.

In addition, based on the information provided in the table 3 , most of respondents gave an 'agree' opinion for types of texts offered to the translation classes. Their agreement is clearly seen from a great number of the respondents for each the following texts; biography (2 disagree and 17 agree, 18 strongly agree), then CV (30 agree and 7 strongly agree). Nevertheless, text number 3 in table above shows that over than half respondents did not expect if 'stand-up comedy' offered as one of the materials in translation classes. This could be seen from number of those numbers ( 3 strongly disagree, 17 disagree while 15 agree and 2 strongly agree).

In another types of text types, the table 4 shows that the respondents expected the translation students learn to translate the 'academic article', 'academic seminar'. The number of the respondents expecting to learn 'academic seminar' 37 (23 agree, 14 strongly agree), however, it is quite smaller than those who willing to learn translating 'academic article', there is 1 respondent answered disagree and 18 of them answered agree while the others (18) stated strongly agree.

Dealing with the text type in translation exercise, the data from the questionnaire revealed that the number of respondents who are willing to translate 'essay', (25 agree, 2 strongly agree and 10 disagree), news (31 agree, 6 strongly agree), written news, (29 agree, 8 strongly agreed) headlines, (1 strongly disagree, 1 disagree, 34 agree, 1 strongly agree) poster, (2 strongly disagree, 2 disagree, 31 agree, 1 strongly agree) are largely bigger compared to those expecting the lecture to provide them with learning material by translating memos, (14 strongly disagree, 7 disagree) while 14 agree, 2 strongly agree.

Further, in relation to the translation activity translating text, table 4 describes that the number of respondents expecting that to translate recipe is fairly bigger than that of respondents willing to translate minutes. The data in the table 4 shows that, 36 respondents ( 15 agree, 21 strongly agree) expected to translate recipe on translation classes while 1 of them answered disagree, and 34 of them expected to translate minutes while only few of respondents (3) did not expect translating minutes in translation course.

In addition, most respondents have a great awareness of the importance of translating tourism and competition brochures as an exercise in translation courses. Most of the respondents admitted that they believe that translating such texts is very important for translation students. As shown in table 4, there are 36 (14 agree, 22 strongly agree) respondents agree that the tourist brochure is used as a translation exercise, while 1 respondent answered disagree. Furthermore, 36 (30 agree, 6 strongly agree) of whom agree to be given a text contest in translation activities, while only 1 disagree. Based on the description before, there is a similarity in the number of respondents who wanted these two texts to be studied in classes, the difference is only in the number of people who agree, where there are 30 people who agree to the text competition and only 14 people agree to the text tourist brochure. However, there are more people who strongly agree (22) answered that they strongly agree for the tourist brochure text and only 6 people stated that they strongly agree to the text competition.

In addition, based on the results of an interview with professional, she stated that this type of translation requires the translator to have special skills, such as knowledge of business jargon, and the industry where the business is located. Other types of translated text can be in the form of travel brochures, cooking recipes, competitions, memos, posters, written news.

Table 4. Text Informative

\begin{tabular}{|c|c|c|c|c|c|}
\hline \multirow[b]{2}{*}{ No } & \multirow[b]{2}{*}{ Text types } & \multicolumn{4}{|c|}{ Response } \\
\hline & & SD & $\mathrm{D}$ & A & SA \\
\hline 1. & $\begin{array}{l}\text { Academic } \\
\text { article }\end{array}$ & & & 23 & \\
\hline 2. & Essay & & 10 & 25 & \\
\hline 3. & $\begin{array}{l}\text { Academic } \\
\text { seminar }\end{array}$ & & 1 & 18 & \\
\hline 4. & News & & & 31 & \\
\hline 5. & Written news & & & 29 & \\
\hline 6. & Headlines & 1 & 1 & 34 & \\
\hline 7. & Poster & 2 & 2 & 31 & \\
\hline 8. & Memos & 7 & 14 & 14 & \\
\hline 9. & Minutes & & 3 & 33 & \\
\hline 10. & $\begin{array}{l}\text { Tourist } \\
\text { brochure }\end{array}$ & & 1 & 14 & \\
\hline 11. & Recipe & & 1 & 15 & \\
\hline 12. & Competition & & 1 & 30 & \\
\hline
\end{tabular}


Table 5. Text Legal Document

\begin{tabular}{|l|l|l|l|l|c|}
\hline \multirow{2}{*}{ No } & \multirow{2}{*}{ Text types } & \multicolumn{4}{|c|}{ Response } \\
\cline { 3 - 5 } & & SD & D & A & SA \\
\hline 1. & Business & & & 15 & 22 \\
\hline 2. & Diplomacy & & & 14 & 23 \\
\hline 3. & Military & & 1 & 12 & 24 \\
\hline 4. & Contract & & & 17 & 20 \\
\hline 5. & Deeds & & 1 & 34 & 2 \\
\hline 6. & Police report & & 1 & 20 & 16 \\
\hline 7. & $\begin{array}{l}\text { Personal } \\
\text { correspondence }\end{array}$ & & & 32 & 5 \\
\hline
\end{tabular}

Based on the result questionnaire distributed to the respondents about texts' need in translation course, it is figured out that the number of students expecting to learn legal document (business document, diplomacy document, military document, deeds, police report, personal correspondence, contract agreement letter) are got scores with the average 3.01-4.00. In other words, those kinds of legal document are needed by the students. This could be seen from the data presented in table 5 indicating that 37 (15 agree, 22 strongly agree) of respondents are willing to translate business document in class activity. Then, diplomacy document 37 (14 agree, 23 strongly agree) of them wanted the lecturer provide this text as an exercise in translating legal document.

In addition in the exercise of the text types of legal document, the students based on the information given in the table, expected the instructor of translation to provide those kinds of text that enabling them to practice to translate the text that they believe related to the markets' demand in translation field. Their willingness was clearly seen from a great number of the students, 37 (17 agree, 20 strongly agree) agree if contract agreement letter and personal correspondence (37; 32 agree and, 5 strongly agree) provided as translation practice in translation classes.

Furthermore, from the table 5, it is revealed that more than half of the respondents 36 ( 34 agree and 2 strongly agree) agree that they want to translate 'deeds', while only 1 of them indicated that they do not agree to use the text as a translation exercise. Then there are 36 (20 agree, 16 strongly agree) respondents are willing to translate the police report and 1 answered disagree.

Based on the description of questionnaire and data above, it can be revealed that over than half students expect lecturer provided legal document as translation practice in translation program. Meanwhile, students said that, legal document translation needs the services of an expert that is highly knowledgeable in legal terms and practices. Translating legal documents needs accurate and correct translation and is one of the most difficult among all translation work.

\section{Materials lacks}

Lack is the difference between the student's present competence and the desire competence. Moreover, based on English for Specific Purpose book lack is about to find out the gap between students' current proficiency and the target proficiency, so that the teacher or the facilitator can decide which of the necessities the learner's lack [3].

The results of lacks were analyzed by looking at the importance of this text being taught to students of translation and the market needs of this text also considered. In other words, most of respondents have a great awareness of the important of translating text types (talk show, diplomacy document, military documents, minutes, deeds, police report and personal correspondence) in order to meet the market demand of translation.

Furthermore, regarding the results of the interview, instructor stated that there were several types of text that had not been given to translation students even though these texts are needed by students after they graduated, they are; technical texts and types of medical technology. Further, another instructor also points out that students are expected to be able to explore for themselves various types of texts that had not been studied in classes.

Meanwhile, to find out more about the types of texts needed in the demands of the translation market, interviews were conducted with professional who has worked at one of the translation agencies in Jakarta, he stated that there are several text types that related to the translation market needs today, such as political, oil and gas, criminal, banking, and insurance texts. Then one of professional also stated that 'we basically refer to the activity of translating court documents like depositions, minutes of meetings, expert testimonies, witness testimonies, judgments, letters rogatory, interviews and more basically, activities related to case'.

Based on the findings of analysis from the results of the questionnaires given to respondents and the interviews conducted, it can be concluded there are 15 text types are needed in the translation classes and classified as lacks of text types because those text types are not taught in the translation classes but those texts needed in translation market demands.

Table 6. Results Lacks of Text Types

\begin{tabular}{|l|l|l|l|l|l|}
\hline NO & Text Types & ST & AL & PR & LEC \\
\hline 1. & Business document & $\sqrt{ }$ & $\sqrt{ }$ & $\sqrt{ }$ & $\sqrt{ }$ \\
\hline 2. & Diplomacy document & $\sqrt{ }$ & $\sqrt{ }$ & $\sqrt{ }$ & $\sqrt{ }$ \\
\hline 3. & Military document & $\sqrt{ }$ & $\sqrt{ }$ & $\sqrt{ }$ & $\sqrt{ }$ \\
\hline 4. & Minutes & - & - & $\sqrt{ }$ & $\sqrt{ }$ \\
\hline 5. & Deeds & - & - & $\sqrt{ }$ & $\sqrt{ }$ \\
\hline 6. & $\begin{array}{l}\text { Personal } \\
\text { correspondence }\end{array}$ & $\sqrt{ }$ & $\sqrt{ }$ & $\sqrt{ }$ & $\sqrt{ }$ \\
\hline 7. & Political & - & - & $\sqrt{ }$ & $\sqrt{ }$ \\
\hline 8. & Gas & - & & $\sqrt{ }$ & $\sqrt{ }$ \\
\hline 9. & Oil & - & & $\sqrt{ }$ & $\sqrt{ }$ \\
\hline 10. & Criminal & $\sqrt{ }$ & $\sqrt{ }$ & $\sqrt{ }$ & $\sqrt{ }$ \\
\hline 11. & Banking & - & - & $\sqrt{ }$ & $\sqrt{ }$ \\
\hline 12. & Insurance & - & - & $\sqrt{ }$ & $\sqrt{ }$ \\
\hline 13. & Expert testimonies & - & - & $\sqrt{ }$ & $\sqrt{ }$ \\
\hline 14. & Witness testimonies & - & - & $\sqrt{ }$ & $\sqrt{ }$ \\
\hline 15. & Letters rogatory & - & - & $\sqrt{ }$ & $\sqrt{ }$ \\
\hline
\end{tabular}




\section{B. Discussion}

Considering the necessity emerging from the target situation the students are involved in future professional settings or students career in translation, the materials shouldn't be limited to the texts extracted from the students' discipline resources bust also documents utilized in business life like formal letters, fax message, report, insurance, banking, contract agreement letter, diplomacy document, minutes, military document should be integrated into the course syllabus. Furthermore, there is a need to establish a connection between the educational context and the labor market. This finding was in line with the findings of the researchers which is conducted by Masitowarni and Sylvana [9]. The result of her study was found that; from nine aspects questioned to the potential English teachers, most of them (92\%) said that the translation's textbook base on TEFL Pedagogical purpose was significantly needed. Therefore, English Education Study Program (EESP) in Indonesia should use translation for teaching English purpose not for professional career in translation. Although this study about need analysis of translation subject, this research had different; the current study analyze about translation materials that offered in translation syllabus and takes a place on Padang, Indonesia. Other researchers [8] found that providing a genre-based syllabus for a translation courses, and bringing real world into the classroom cause an innovative learning atmosphere. The suggested lesson plan during this study promotes more student activity and involvement by presenting theoretical knowledge, offering hands on activities and projects which enhance students' creativity in order to meet the demands of translation texts. While the previous research talked about material's need of translation course that related to the translation market.

Furthermore, the interview results conclude that translated material linked with text must cover the wants of the market. Text is not only limited to descriptive, analytical or report but much broader than that, like documents related to the fields of health, business, marketing or religious texts. This result is similar with the research that conducted by Volga [16] found that, from the attitude of varied stakeholders, mainly the graduates of translatortraining programs at the undergraduate level. This study derives from the necessity for inquiry on what the market expects from translators and the way training programs meet these expectations. The purpose of departure during this study was that translator training and the translation market as two parties to translation service provision should be in close interaction so as to enhance the standard of coaching and quality of text types selected in higher education institutions. The materials should meet the market demand by providing texts; technical text, diplomacy document and military document. Regarding these findings related to material needs it is very important to be implemented as a reference for teachers, lecturers and syllabus designers to prepare graduates to be ready in fieldwork.

\section{CONCLUSION}

In conclusion, the results of this study are expected to provide valuable information about the needs of translation materials in Universitas Negeri Padang. Translations' material should take into consideration the rapid social changes and challenge translators or would be translators are faced with. It is important to get big attention for development of learning materials because syllabus designer is required to be sensitive to the development needs of students' career as translator. It is should get big attention for development of learning materials because teachers and curriculum developers are required to be sensitive to the development needs of students and society. The teacher and curriculum developer should be aware with the users' need analysis in order to maximize the quality of the students after graduate from the university.

\section{REFERENCES}

[1] Ardi. P, "Developing a Teaching Methodology of Translation Course: a Cooperative Learning Model for English Department Students," Indonesian Journal of Language Studies. Vol., 2, No., 1. February 2016.

[2] Gerding-Seles, "Teaching Translation: Problems and solutions," Translation Journal 4(3)http://translationjournal.net/journal/13edu.htm

[3] H.T. and Alan Waters, "Need Analysis: English for Specific Purposes," Eds. Cambridge: Cambridge University Press: 53-64, 1987.

[4] Nunan. D, "The Learned-Centred Curriculum," Cambridge: Cambridge University Press, 1998.

[5] Navid and Zahra. B, "Students' Need Analysis for Translation Studies Curriculum Offered at Master Level in Iranian University," Published in Academia. Submission date, March 13, 2016.

[6] L. Cancerel and Ricard, "Identifying the Needs of Adults Learning Foreign Language, Oxford," Pergamon Press for the Council of Europe, 1980.

[7] E. Manipuspita, "Developing Materials for Teaching Translation at non Translation Department," Jurnal Linguistik Terapan, May 23, 2018.

[8] Sedu and Sezar, "Studies in The Development of Translation Competence Ph.D. Dissertation," Alkalmazott Nyelveszeti Program, 2015.

[9] M. Siregar, Silvana and Amri, "Need Analysis For Develoving Translation's Textbook Based on TEFL Pedagogical Purpose in Indonesia," Indonesian Journal of Language Studies. Vol. 9. No. 3, May 2018.

[10] M. Siregar, Silvana and Amri, "Need Analysis For Develoving Translation's Textbook Based on TEFL Pedagogical Purpose in Indonesia," Indonesian Journal of Language Studies. Vol. 9, No. 3, May 2018.

[11] C. Meta, "Theory in Translation Training," Pub. Co., Available from: eBook Academic Collection 
(E) BSCOhost. December 12, 2015.

[12] A. Adrien, "Translation in Foreign Language Teaching: A Brief Overview of Pros and Cons," Eger Journal English Studies, 10, 80-91. 2011.

[13] F. Coban, "Analysis and Training the Required Abilities in Translation in Light of Translation Model and General Theories of Translation Studies," $7^{\text {th }}$ World Conference of Education Science, (WCES.2015) 05-07 February. Novotel Athens Convention Center, Athens, Greece, 2015.

[14] L. R. Gay and P. Airasian, "Education Research: Competencies for Analyss and Aplication (Ninth Edition)," New Jersey: Pearson Education, 2009.

[15] L. R. Gay and P. Airasian, "Education Research: Competencies for Analyss and Aplication (Sixth Edition)," New Jersey: Pearson Education, 2000.

[16] V. Yilmaz, "Training Translator for Marketing in Turkey: What Should We Teach in Future Translator?," Australian International Journal Academic Centre: Australia, Vol,. 5. No.1, January 2017. 